\title{
Clinical and laboratory factors affecting chronicity in children diagnosed with immune thrombocytopenia
}

\author{
Immun trombositopenili çocuklarda kronikleşmeyi etkileyen klinik ve laboratuvar \\ faktörler
}

Yılmaz Ay, Hakan Sarbay

Gönderilme tarihi:28.02.2020

Kabul tarihi:28.04.2020

\begin{abstract}
Purpose: Immune thrombocytopenia (ITP) is one of the most common hematologic disorders in childhood. Approximately $20-25 \%$ of patients with newly diagnosed ITP become chronic. We aimed to investigate the risk factors that may affect chronicity of ITP.

Materials and methods: A total of 75 pediatric patients with ITP who were admitted to the Pediatric Hematology Department of Pamukkale University Faculty of Medicine Hospital between January 2013 and July 2018 were included in the study. 17 of the 75 cases were excluded, because 13 of those had lack of data in the system and 4 of those were persistent ITP. The patients' characteristics such as clinical features, laboratory results, treatment requirements and type of treatment were retrospectively evaluated using the hospital's information system.

Results: $46(79.3 \%)$ of the 58 patients with ITP were acute and $12(20.7 \%)$ of those were chronic. The mean age of the patients with acute ITP was $4 \pm 3.84$ years, while the mean age of the patient with chronic ITP was $9.6 \pm 4.6$ years. Statistical analysis revealed that children with a diagnosis age greater than 10 years had a significantly higher rate of chronicity. The dominant season in acute cases was spring with $34.8 \%$, while in chronic cases it was summer with $50 \%$. Acute cases were significantly higher in the spring season. 26 of 46 patients with acute ITP $(56.5 \%)$ and 3 of 12 patients with chronic ITP $(25 \%)$ were treated with IVIG firstly.

Conclusion: We determined that in newly diagnosed patients with ITP who are older 10 years of age and no history of infection may have high risk of chronicity, while the patients diagnosed in the spring and administered IVIG may have less chronicity.
\end{abstract}

Key words: Immune thrombocytopenia, pediatric, chronic.

Ay $\mathrm{Y}$, Sarbay H. Clinical and laboratory factors affecting chronicity in children diagnosed with immune thrombocytopenia. Pam Med J 2020;13:535-540.

Özet

Amaç: İmmun trombositopeni (ITP) çocukluk çağında en sık görülen hematolojik hastalıklardan biridir. Yeni tanı almış ITP hastalarının yaklaşık \%20-25'i kronikleşmektedir. Bu çalışmada, ITP'li çocuk hastalarda kronikleşmeye etki eden risk faktörlerini araştırmayı amaçladık.

Gereç ve yöntem: Ocak 2013-Temmuz 2018 tarihleri arasında Pamukkale Üniversitesi Tıp Fakültesi Hastanesi Çocuk Sağlığı ve Hastalıkları Hematoloji Bilim Dalı'na başvuran ve ITP tanısı alan toplam 75 çocuk hasta çalışmaya dahil edildi. 13 hasta veri eksikliği nedeniyle ve 4 hasta persistan ITP olması nedeniyle çalışmadan çıkarıldı. Hastaların klinik özellikleri, laboratuvar sonuçları, tedavi gereksinimleri ve uygulanan tedaviler hastanenin bilgi sisteminden geriye dönük olarak elde edildi.

Bulgular: ITP tanılı 58 hastanın 46'sı (\%79,3) akut ve 12'si (\%20,7) kronikti. Akut iTP'li hastaların yaş ortalaması

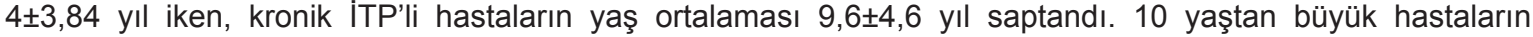
kronikleşme oranı anlamlı olarak daha yüksekti. Akut olguların \%34,8'si ilkbaharda tanı almışken, kroniklerin \%50'si yaz mevsiminde tanı almıştı. Akut olgular anlamlı olarak daha yüksek oranda ilkbaharda başvurmuştu. Akut ITP'li 46 hastanın 26'sına (\%56,5) ve kronik ITP'li 12 hastanın 3'üne (\%25) ilk tedavi olarak intravenöz immunglobulin (IVIG) uygulanmıştı.

Sonuç: 10 yaşından büyük ve enfeksiyon öyküsü olmayan yeni tanı ITP hastalarının kronik seyir gösterme olasılığı daha yüksek iken, ilkbaharda tanı alan ve ilk tedavide IVIG uygulanan hastalarda kronikleşme riskinin daha düşük olduğu saptanmıştır.

Anahtar kelimeler: İmmun trombositopeni, çocuk, kronik.

Ay Y, Sarbay H. İmmun trombositopenili çocuklarda kronikleşmeyi etkileyen klinik ve laboratuvar faktörler. Pam Tip Derg 2020;13:535-540.

Yılmaz Ay, Assoc. Prof. Pamukkale University Faculty of Medicine, Pediatric Hematology and Oncology, Denizli, Turkey, e-mail: dryilmazay@ yahoo.com (orcid.org/0000-0002-5525-5647) (Corresponding Author)

Hakan Sarbay, Ass. Prof. Istanbul Yeni Yuzyıl University Faculty of Medicine, Pediatric Hematology and Oncology, Istanbul, Turkey, e-mail: drhakansarbay@hotmail.com (orcid.org/0000-0002-6332-2213) 


\section{Introduction}

Immune thrombocytopenia (ITP), which was previously known as idiopathic thrombocytopenic purpura, is one of the most common hematologic disorders in childhood. Incidence of ITP is 4-8 per 100.000 children each year. $50-80 \%$ of newly diagnosed ITP patients have a history of infection or vaccination in the last month [1]. ITP is characterized by autoimmune mechanisms which cause increased platelet destruction and disruption of platelet production. [2]. Secondary causes such as pregnancy, medication or other autoimmune disease should be excluded for the diagnosis of ITP. In 2009, an international consensus report on the definition and phases of ITP was prepared. According to this report, the lower limit for thrombocytopenia in patients with ITP was accepted as $100 \times 10^{3}$ $/ \mu \mathrm{L}$. The newly diagnosed ITP phase (acute) refers to the first 3 months from diagnosis. The definition of persistent ITP includes cases that are not present in spontaneous remission at 3-12 months from the diagnosis and cannot stay in remission when treatment is discontinued. Chronic ITP has been used for cases lasting 12 months or more [3]. Approximately $20-25 \%$ of patients with newly diagnosed ITP develop chronic ITP [4].

It is unclear how long the patients will be in remission at the time of diagnosis and whether they will be chronic or not. Therefore, there are several studies in newly diagnosed ITP patients to give insight to the physician about the course of the disease. $[4,5]$. In our study, we aimed to investigate the risk factors that may affect chronicity of ITP.

\section{Materials and methods}

A total of 75 pediatric patients with ITP who were admitted to the Pediatric Hematology Department of Pamukkale University Faculty of Medicine Hospital between January 2013 and July 2018 were included in the study. The patients' characteristics such as clinical features, laboratory results, treatment requirements and type of treatment were retrospectively evaluated using the hospital's information system. 17 of the 75 cases were excluded, because 13 of those had lack of data in the system and 4 of those were persistent
ITP. This retrospective study was approved by the Pamukkale University Non-invasive Clinical Research Ethics Committee.

Clinical and laboratory features of the patients were evaluated. These are gender ( $F$ ( M), mean age, year of diagnosis, age of first diagnosis as 10 or less, no history of infection in the last month, presence of vaccination history in the last month, insidious onset (randomly less than $100.000 / \mathrm{mm}^{3}$ platelet counts), platelet count, initial platelet counts above 20.000/ $\mathrm{mm}^{3}$, positive anti-nuclear antibody (ANA titre $\geq 1 / 100$ significant positive), presence of mucosal hemorrhage at the time of diagnosis, helicobacter pylori antigen positivity, treatments.

\section{Statistical analysis}

The normality of distribution of continuous variables was tested by Mann Whitney $U$ test. Continuous variables are expressed as mean \pm standard deviation and categorical variables as number and percentage. Chi-square test applied to investigate relationship between two categorical variables. Statistical analysis was performed with SPSS Windows version 24.0 and a $p$ value $<0.05$ was accepted as statistically significant.

\section{Results}

As initial therapy of 58 patients; 12 patients were received corticosteroid, 29 patients were administered intravenous immunoglobulin (IVIG), 2 patients were given combination therapy of corticosteroid and IVIG and also 14 patients were followed up without treatment. 46 $(79.3 \%)$ of the 58 patients with ITP were acute and $12(20.7 \%)$ of those were chronic. The mean age of the patients with acute ITP was $4 \pm 3.84$ years, while the mean age of the patient with chronic ITP was $9.6 \pm 4.6$ years. When the patients were evaluated according to their gender; $41 \%$ of 12 chronic cases were female and it was not statistically significant $(p=0.358)$. While $7(58.3 \%)$ of the 12 chronic cases were older than 10 years of diagnosis age, 9 (19.5\%) of the 46 acute cases were greater than 10 years of diagnosis age. In other words, $43.7 \%$ of 16 patients with a diagnosis age greater than 10 years have a chronic course. The rate of patients older than 10 years was higher in chronic ITP group than that of acute ITP group $(p=0.028)$. 
A total of 32 patients with no history of infection in the last 1 month; 10 cases were chronic (31.2\%) and 22 patients were acute (68.8\%). $83.3 \%$ of chronic patients (10/12) and $47.8 \%$ of acute patients $(22 / 46)$ had no history of infection. Although the findings were not statistically significant, they were found close to the significant value limit $(p=0.097)$. There was no vaccination history in patients with chronic ITP before diagnosis. The results were not significant due to lack of data. 6 patients with ITP were insidious onset. One of them (16\%) was chronic and $5(84 \%)$ were acute. The data obtained were not statistically significant.

When the patients were evaluated according to the season they were diagnosed; 16 (34.8\%) of 46 patients with acute ITP were diagnosed in the spring, $12(26.1 \%)$ were in summer, 7 $(15.2 \%)$ in autumn, and $11(23.9 \%)$ in the winter. In 12 patients with chronic ITP, 2 (16.7\%) were diagnosed in spring, $6(50 \%)$ in summer and $4(33.3 \%)$ in autumn. The dominant season in acute cases was spring with $34.8 \%$, while in chronic cases it was summer with $50 \%$. Acute cases were significantly higher in the spring season $(p=0.026)$.

When the platelet count at the time of diagnosis is evaluated; there were 11 patients with a platelet count $>20,000 / \mathrm{mm}^{3}$. $3(27 \%)$ of those were chronic and $8(73 \%)$ of those were acute. In other words, $25 \%$ of chronic cases and $17.7 \%$ of acute cases have a platelet count above $20.000 / \mathrm{mm}^{3}$ at the time of diagnosis. These results were not statistically significant $(p=0.681) .6$ of the 17 patients who underwent ANA testing were positive (1/100 titer and above) and 7 were negative. Two of the ANA positive patients were acute and 4 were chronic, while 4 of the ANA negative patients were acute. This result was not statistically significant $(p=0.592)$.

26 of the 29 patients who treated firstly with IVIG were acute and 3 were chronic. In other words, 26 of 46 patients with acute ITP $(56.5 \%)$ and 3 of 12 patients with chronic ITP $(25 \%)$ were treated with IVIG firstly. It was found that patients who received IVIG in the first treatment had significantly less chronic status $(p=0.038) .9$ of 13 patients who were treated with steroids initially were acute $(69.2 \%)$ and $4(31.8 \%)$ were chronic. It was not statistically significant $(p=0.437)$. Two patients who received combination therapy (steroids and IVIG) in the first treatment were also chronic. Of the 14 patients without treatment, $23.9 \%(11 / 46)$ were acute and $25 \%$ (3/12) were chronic. These results were not statistically significant.

There were 21 patients with mucosal bleeding at the time of diagnosis. 16 of those $(76.2 \%)$ were an acute and 5 of those $(23.8 \%)$ were chronic. In other words, $34.8 \%$ of the patients with acute ITP and $41.7 \%$ of the patients with chronic ITP had mucosal bleeding at the time of diagnosis. These results were not statistically significant $(p=0.741)$. There was not life threatening bleeding in this study group.

Only 1 out of 7 patients who were analyzed Helicobacter Pylori antigen in stool was positive. Due to the small number of tests performed, it was not evaluated statistically. Clinical, laboratory and demographic characteristics of the patients have been shown in Table 1. 
Table I. Clinical, laboratory and demographic characteristics of the patients

\begin{tabular}{llll}
\hline Risk factors & Acute ITP $(\mathrm{n}=46)$ & Chronic ITP $(\mathrm{n}=12)$ & $p$ value \\
\hline Mean age (years) & $4 \pm 4.6$ & $9.6 \pm 3.84$ & 0.006 \\
$\pm \mathrm{SD}$ & & & 0.358 \\
Gender & $26 / 20$ & $5 / 7$ & \\
(Female / Male) & & & 0.028 \\
Age > 10 years & $9(19.5 \%)$ & $7(58.3 \%)$ & 0.097 \\
No infection history & $22(47.8 \%)$ & $10(83.3 \%)$ & 1.00 \\
No vaccine history & $43(93.4 \%)$ & $12(100 \%)$ & 0.741 \\
Mucosal bleeding at the time of diagnosis & $16(34.8 \%)$ & $5(41.7 \%)$ & 0.026 \\
Diagnosis season: spring & $16(34.8 \%)$ & $2(16.7 \%)$ & 0.681 \\
Platelet count >20.000 /mm ${ }^{3}$ & $8(17.4 \%)$ & $3(25 \%)$ & 0.437 \\
Steroid in initial treatment & $8(17.4 \%)$ & $4(33.3 \%)$ & 0.038 \\
IVIG in initial treatment & $26(56.5 \%)$ & $3(25 \%)$ & 0.106 \\
IVIG and steroid combination in initial treatment & 0 & $2(16.7 \%)$ & 1.000 \\
Untreated follow-up & $11(23.9 \%)$ & $3(25 \%)$ & \\
\hline
\end{tabular}

ITP: immune thrombocytopenic purpura, IVIG: intravenous immunglobulin, SD: standart deviation

\section{Discussion}

ITP is a heterogeneous disease in terms of clinical, laboratory, and pathophysiological [6]. $75-80 \%$ of pediatric patient with ITP have remission within 6 months. However, it has been reported that the chronic pediatric ITP ratio are $23 \%, 28 \%$ and $47 \%$ respectively at diagnosis age of 3-12 months, 1-10 years and older than 10 years [6]. It is not clear whether the patient will be in remission and stay in remission. Also It is not feasible to predict if the patient will need treatment and remain in remission. In some patients, remission is achieved without treatment; on the other hand, even splenectomy is not beneficial in some patients. Studies are underway to determine the risk factors that may be a clue in the process of chronicity and to find the right treatment strategy for each patient.

In our study, we examined the risk factors developed by the Nordic Department of Pediatric Hematology and Oncology (NOPHO) [7] and by the meta-analysis published by Heitink Polle et al. [5]. We have found that there is no statistically significant difference between genders in terms of chronicity. However, according to the results published by NOPHO, female gender in all age groups is at risk about chronicity [7].
Kühne et al. [8] reported that the mean age of diagnosis was 5.7 in 20131 patients with newly diagnosis ITP. $70 \%$ of these patients were between 1-10 years, $10 \%$ were between $3-12$ months and $20 \%$ between $10-16$ years of age [8]. Boys and girls were equally affected [8]. In our study, mean age of the patients with acute ITP was 4 years, while mean age of the patients with chronic was 9,6 years. Chronic course was significantly higher in patients older than 10 years. In the literature, the risk of chronicity in pediatric patients with ITP increases as the age grows, and the risk limit age is 11 years $[4,6$, 9-17].

Studies show that pre-disease viral infections and vaccines play a role in the pathogenesis of ITP [2, 4]. This is due to the fact that the crossreactions trigger autoimmune mechanisms, platelet clearance in the viremic phase and negatively affected thrombopoiesis. [18]. Three studies in this subject recently revealed that the lack of infection and vaccination history of the patient correlates with the progress of chronic disease development [7, 9, 11]. However, in this study, there was no history of vaccine or infection of the patients in the last 4 months. This opposite relationship between the history of viral disease and chronic course explains the acute disease of peaking in winter and spring 
when viral infection is most common [4]. In our study, it was observed that patients who were diagnosed with ITP in spring had remission in the acute period and none of the patients diagnosed in winter were chronic.

In this study, it was found that mucosal bleeding and platelet count at the time of diagnosis did not have an effect on remission. Nevertheless, EIAlfy et al. [4] have revealed that absence of mucosa bleeding and platelet count above $20.000 / \mathrm{mm}^{3}$ are the risk factors for chronic course. These two criteria also support the fact that insidious onset may be a risk factor for chronicity.

Considering the treatment requirements and treatments given, in the study, it was found that starting with IVIG treatment was more successful with regard to remission of the disease than other treatment modalities. Although Akbayram et al. [9] have reported that IVIG and steroid are equally effective, Heitink-Pollé et al. [5] have emphasized that IVIG therapy is more effective. The contribution of IVIG treatment to remission is explained by long-term immunomodulatory effect [5].

ANA and helicobacter pylori antigen test in stool, which are considered to be risk factors for chronicity, could not be evaluated because there is not enough data.

The main factors limiting our study are the low number of patients, and so some of the risk factors data could not be compared.

In conclusion, we determined that in newly diagnosed patients with ITP who are older 10 years of age and no history of infection may have high risk of chronicity, while the patients diagnosed in the spring and administered IVIG may have less chronicity. To estimate the chronic course in ITP; larger patient series, more regular recording system and prospective studies are needed.

Conflict of interest: No conflict of interest was declared by the authors.

\section{References}

1. Higashigawa M, Maeyama T, Yoshino A. Incidence of childhood idiopathic thrombocytopenic purpura. Pediatr Int 2015;57:1041-1043. https://doi.org/10.1111/ ped. 12788
2. Cines DB, Cuker A, Semple JW. Pathogenesis of immune thrombocytopenia. Presse Med 2014;43:4959. https://doi.org/10.1016/j.lpm.2014.01.010

3. Rodeghiero F, Stasi R, Gernsheimer T, et al. Standardization of terminology, definitions and outcome criteria in immune thrombocytopenic purpura of adults and children: report from an international working group. Blood 2009;113:2386-2393. https://doi. org/10.1182/blood-2008-07-162503

4. ElAlfy M, Farid S, Abdel Maksoud A. Predictors of chronic idiopathic thrombocytopenic purpura. Pediatr Blood Cancer 2010;54:959-962. https://doi. org/10.1002/pbc.22481

5. Heitink Pollé K, Nijsten J, Boonacker C, Boonacker CW, de Haas M, Bruin MC. Clinical and laboratory predictors of chronic immune thrombocytopenia in children: systematic review and meta-analysis. Blood 2014;124:3295-3307. https://doi.org/10.1182/ blood-2014-04-570127

6. Kühne $\mathrm{T}$, Buchanan $\mathrm{GR}$, Zimmerman $\mathrm{S}$, et al. A prospective comparative study of 2540 infants and children with newly diagnosed idiopathic thrombocytopenic purpura (ITP) from the Intercontinental childhood ITP study group. J Pediatr 2003;143:605-608. https://doi.org/10.1067/s00223476(03)00535-3

7. Zeller B, Rajantie J, Hedlund-Treutiger I, et al. Childhood idiopathic thrombocytopenic purpura in the Nordic countries: epidemiology and predictors of chronic disease. Acra Paediatr 2005;94:178-184. https://doi.org/10.1111/j.1651-2227.2005.tb01887.x

8. Kühne $\mathrm{T}$, Imbach $\mathrm{P}$, Bolton Maggs $\mathrm{PH}$, Berchtold W, Blanchette V, Buchanan GR. International Childhood ITP Study Group. Newly diagnosed idiopathic thrombocytopenic purpura in childhood: an observational study. Lancet 2001;358:2122-2125. https://doi.org/10.1016/S0140-6736(01)07219-1

9. Akbayram S, Dogan M, Ustyol L, et al. The clinical outcome of 260 pediatric ITP patients in one center. Clin Appl Thromb Hemost 2011;17:30-35. https://doi. org/10.1177/1076029610379849

10. Bruin M, Bierings $M$, Uiterwaal $C$, et al. Platelet count, previous infection and FCGR2B genotype predict development of chronic disease in newly diagnosed idiopathic thrombocytopenia in childhood: results of a prospective study. Br J Haematol 2004;127:561-567. https://doi.org/10.1111/j.1365-2141.2004.05235.x

11. Glanz J, France E, Xu S, Hayes T, Hambidge S. A population-based, multisite cohort study of the predictors of chronic idiopathic thrombocytopenic purpura in children. Pediatrics 2008;121:506-512. https://doi.org/10.1542/peds.2007-1129 
12. Intercontinental Childhood ITP Study Group32, Kubota M, Usami I, Kobayashi K, Tsutsui T, Matsubara K. Serum immunoglobulin levels at onset: association with the prognosis of childhood idiopathic thrombocytopenic purpura. Int J Hematol 2003;77:304-307. https://doi. org/10.1007/bf02983791

13. Roganovic J, Letica Crepulja M. Idiopathic thrombocytopenic purpura: a 15-year natural history study at the Children's Hospital Rijeka, Croatia. Pediatr Blood Cancer 2006;47:662-664. https://doi. org/10.1002/pbc.20995

14. Sohn YM, Park CS, Kim KY. Idiopathic thrombocytopenic purpura in children: clinical prognosis and evaluation of treatment. Yonsei Med J 1986;27:6775. https://doi.org/10.3349/ymj.1986.27.1.67

15. Yaprak I, Atabay B, Durak I, Türker M, Öniz H, Arun Özer E. Variant clinical courses in children with immune thrombocytopenic purpura: Sixteen year experience of a single medical center. Turk J Hematol 2010;27:147155. https://doi.org/10.5152/tjh.2010.21

16. Watts RG. Idiopathic thrombocytopenic purpura: a 10year natural history study at the childrens hospital of alabama. Clin Pediatr (Phila) 2004;43:691-702. https:// doi.org/10.1177/000992280404300802

17. Simons SM, Main CA, Yaish HM, Rutzky J. Idiopathic thrombocytopenic purpura in children. J Pediatr 1975;87:16-22. https://doi.org/10.1016/s00223476(75)80061-8

18. Rand ML, Wright JF. Virus associated idiopathic thrombocytopenic purpura. Transfus Sci 1998;19:253259. https://doi.org/10.1016/s0955-3886(98)00039-3

Acknowledgement: We would like to thank to Mervenur Sahin and Seher Yilmaz for their contributions.

Ethics committee approval: Pamukkale University Non-invasive Clinical Research Ethics Committee (date: 05.12.2018 and number: 60116787-020/83142).

\section{Contributions of authors}

Y.A. asserted the main idea and hypothesis of the study. Y.A. developed the theory and edited the material and method section. Y.A. and H.S. evaluated the results. The discussion of the article was written by Y.A. and H.S., Y.A. and H.S. reviewed, made the necessary corrections and approved them. 